\title{
A Pandemic within Other Pandemics. When a Multiple Infection of a Host Occurs: SARS-CoV-2, HIV and Mycobacterium tuberculosis
}

\author{
Carmen María González-Domenech 1,2,*i], Isabel Pérez-Hernández ${ }^{3}$, Cristina Gómez-Ayerbe ${ }^{1,4}$, \\ Isabel Viciana Ramos ${ }^{1,4}$, Rosario Palacios-Muñoz ${ }^{1,4}$ and Jesús Santos ${ }^{1,4}{ }^{(D}$ \\ 1 Clinical Research in HIV Infection, Endovascular Infection and Bacteriemia, \\ Biomedical Research Institute of Malaga (IBIMA), 29010 Malaga, Spain; cgayerbe@gmail.com (C.G.-A.); \\ isaviciana@hotmail.com (I.V.R.); rosariopalaci@gmail.com (R.P.-M.); med000854@gmail.com (J.S.) \\ 2 Department of Microbiology, Faculty of Sciences, University of Malaga, 29071 Malaga, Spain \\ 3 Internal Medicine Service, Melilla Regional Hospital, 52005 Melilla, Spain; isaperezhernandez@gmail.com \\ 4 Infectious Diseases and Clinical Microbiology Unit, Virgen de la Victoria Hospital, 29010 Malaga, Spain \\ * Correspondence: iadomenech@gmail.com
}

\section{check for} updates

Citation: González-Domenech, C.M.; Pérez-Hernández, I.; Gómez-Ayerbe,

C.; Viciana Ramos, I.;

Palacios-Muñoz, R.; Santos, J. A

Pandemic within Other Pandemics.

When a Multiple Infection of a Host Occurs: SARS-CoV-2, HIV and Mycobacterium tuberculosis. Viruses 2021, 13, 931. https://doi.org/ 10.3390/v13050931

Academic Editor: Herve J A Fleury

Received: 15 April 2021

Accepted: 16 May 2021

Published: 17 May 2021

Publisher's Note: MDPI stays neutral with regard to jurisdictional claims in published maps and institutional affiliations.

Copyright: (c) 2021 by the authors. Licensee MDPI, Basel, Switzerland. This article is an open access article distributed under the terms and conditions of the Creative Commons Attribution (CC BY) license (https:// creativecommons.org/licenses/by/ $4.0 /)$.
Abstract: By the middle of 2021, we are still immersed in the coronavirus disease 2019 (COVID19) pandemic, caused by the severe acute respiratory syndrome coronavirus 2 (SARS-CoV-2). The concurrence of this new pandemic in regions where human immunodeficiency virus (HIV) and tuberculosis (TB) infections possess the same epidemiological consideration, has arisen concerns about the prognosis, clinical management, symptomatology, and treatment of patients with triple infection. At the same time, healthcare services previously devoted to diagnosis and treatment of TB and HIV are being jeopardized by the urgent need of resources and attention for COVID-19 patients. The aim of this review was to collect any article considering the three conditions (HIV, TB, and SARS-CoV-2), included in PubMed/Medline and published in the English language since the beginning of the COVID-19 pandemic. We focused on detailed descriptions of the unusual cases describing the three co-infections. Eighty-four out of 184 publications retrieved met our inclusion criteria, but only three of them reported cases (five in total) with the three concomitant infections. The clinical evolution, management, and therapy of all of them were not different from mild/severe cases with exclusive COVID-19; the outcome was not worse either, with recovery for the five patients. Cases of patients with COVID-19 besides HIV and TB infections are scarce in literature, but studies deliberately embracing the triple infection as a priori inclusion criterion should be carried out in order to provide a complete understanding of joint influence.

Keywords: SARS-CoV-2; COVID-19; HIV; tuberculosis; coinfection; triple-infection

\section{Introduction}

According to UNAIDS global human immunodeficiency virus (HIV) statistics, there were over 38 million people worldwide living with HIV (PLWHIV) at the end of 2019. Most of cases are concentrated in sub-Saharan Africa; among the most devastated countries by HIV epidemic, South Africa possesses the highest number of PLWHIV [1]. Untreated HIV replication causes a wide range of immunological dysfunction, with a progressive loss of CD4(+) T cell and B cell functionality, leading to an increased risk of opportunistic infections and carcinogenic events [2-4]. In this context, pneumonia by different pathogens was a leading cause of morbidity and mortality before the institution of antiretroviral therapy (ART) [5]. Afterwards, the implementation of ART from the mid-1990s substantially improved HIV patients' quality of life and life expectancy to such an extent that they are currently close to those for individuals without HIV infection [6-8]. However, far from being an eradication treatment, ART must currently be taken for life. As well-known and 
presently unsolved, there exists a main obstacle for a functional or sterilizing cure of the HIV infection: its viral latency and ability to rebound viremia following ART interruption. HIV possesses plenty of molecular mechanisms targeted to establish and maintain a latent infection, and, as a consequence, a chronic immune disorder (for a review see [9-11]). Besides the effects of HIV-induced persistent systemic inflammation and the impact of long-term ART on respiratory immune response, the lung is a known reservoir for HIV, so this organ may be exposed to an increased frequency of other pulmonary diseases [12].

For its part, tuberculosis (TB) is an ancient but still present human disease caused by Mycobacterium tuberculosis (MTB), and almost exclusively transmitted through the air $[13,14]$. Worldwide, TB was considered in the global top 10 causes of death at the beginning of this century, falling from 7 th place in 2000 to 13 th in 2019 , with a $30 \%$ reduction in global deaths. Nevertheless, it remains among the top 10 causes of death in the African and SouthEast Asian regions. According to World Health Organization (WHO), over 10 million people fell ill with TB worldwide, and almost one million and a half people died from TB (including 208,000 people with HIV) in 2019. About half of the new TB cases occurred in the South-East Asian region (44\%), followed by the African region (particularly in sub-Saharan Africa), with a quarter new cases $(25 \%)$, and the Western Pacific with approximately a fifth (18\%), according to Global Health Observatory data repository (2020). Two thirds of the number of cases are concentrated in just eight countries, with India leading the count, followed by Indonesia, China, the Philippines, Pakistan, Nigeria, Bangladesh and South Africa [15]. Pulmonary presentation is the most common, although the mycobacteria can spread to other organs or systems (such as skin, liver, central nervous, musculoskeletal and reproductive systems) through the hematogenous route $[16,17]$. Somehow similar to a treatment-controlled HIV patient, with the virus concealed itself in CD4+ T cells, there is a latent TB infection characterized by the pathogen lying dormant inside the lungs, without causing destruction of organs [13,14]. Anyway, PLWVIH and also with a latent TB infection present a higher risk of progressing to active disease, with a predominant extrapulmonary manifestation $[15,16,18]$. Thus, HIV and TB may represent a lethal tandem.

Finally, at the time of writing this review, we are still immersing in the pandemic of coronavirus disease 2019 (COVID-19). The etiological agent is a member of Coronaviridae (CoV) family, named severe acute respiratory syndrome coronavirus 2 (SARS-CoV-2) by the International Committee on Taxonomy of Viruses basing on phylogenetic analysis [19]. This family comprises four major genera: Alphacoronavirus, Betacoronavirus, Gammacoronavirus, and Deltacoronavirus; the two former, the Alpha and Beta-CoVs, have the ability to infect humans $[20,21]$, and cause a range of illnesses, from the common cold to a severe acute respiratory tract infection. The first reported case emerged in Wuhan, Hubei Province, China, in December 2019, and soon turned into a global threat, because of its viral infectivity and its permanent within-host evolution. Since then, the virus has caused over 108 million confirmed cases and almost 2.4 million deaths worldwide at the time of writing (middle of February 2021) [22]. The dominant route of transmission for SARS-CoV-2 is airborne aerosol/droplet, but transplacental transmission is also described [23,24]. After entering the lungs by inhalation, SARS-CoV-2 activates immune system, cytokines, and other pathogenresistance mechanisms. As previously exposed for HIV, acute infection for SARS-CoV-2 is also associated with lymphopenia, and the severe decline of CD4+ T cell counts and B cell dysfunction in COVID-19 patients have been linked to poor clinical outcomes [25-31]. The dynamic of lymphocyte subsets changes in the course of both infections are not comparable though, because SARS-CoV-2 chronification is currently ruled out, unlike HIV [32].

In light of the above, the concurrency of a new pandemic within two other pandemics has jeopardized health care providers for TB and HIV patients. Thus, resources achieved over a long period for control of HIV and TB infections are now being redirected to COVID19. This situation is dramatically evident in many African countries, especially in South Africa [33-36].

In this review, we collected and summarized any research or scientific thought simultaneously considering these three conditions, especially when concerned impact on 
public health. We sought studies reporting unusual cases of a triple infection with Mycobacterium tuberculosis, HIV, and SARS-CoV-2. Differences and similarities in clinical management, respiratory therapy, symptomatology, or outcomes were searched and compared to those from an exclusive SARS-CoV-2 infection.

\section{Materials and Methods}

A literature search for pertinent peer-reviewed publications was conducted using PubMed/Medline electronic database from December 2019 to 16 February 2021, using the following combination of key terms: ["HIV" AND "TUBERCULOSIS" AND "SARSCoV-2"], ["AIDS" AND "CORONAVIRUS" AND "TUBERCULOSIS"], and ["HIV" AND "TUBERCULOSIS" AND "Coronavirus"]. The search was limited to publications in English. Inclusion criteria were systematic and narrative reviews, prospective and retrospective studies, case series and case reports considering the concurrence of the three pathogens in a same host. We especially focused on case reports simultaneously assessing any feature of the three infectious diseases: clinical characteristics, epidemiology, diagnosis, care interventions, prognosis, immunology, treatment, or prevention. The most relevant information was inserted in a spreadsheet, in order to make it to easier analyze the data and present the results in a narrative way.

\section{Results and Discussion}

\subsection{Summary of Literature Search and Selection}

We obtain a total of 105 unique records, out of 184 publications retrieved (Supplementary File S1). According to each set of keywords, ["AIDS" AND "CORONAVIRUS" AND “TUBERCULOSIS"], ["HIV" AND "TUBERCULOSIS" AND "SARS-CoV-2"] and ["HIV" AND “TUBERCULOSIS" AND “CORONAVIRUS"], the outcomes were 32, 70 and 82 , respectively.

Twenty one out of 105 studies were discarded (Supplementary File S2). Two of them were written in a language other than English; thirteen articles left out a mention to any of the three infections, because some of them were done prior to COVID-19 pandemic; other four papers were not considered because co-infection with HIV and/or Mycobacterium tuberculosis was actually an exclusion criterion in such studies; another case report was discarded since patient had a negative HIV serology, as found out when reading the manuscript.

Thus, 84 studies finally met our inclusion criteria (Supplementary File S3), three of them reporting a detailed description of cases with the three concomitant infections: HIV, TB, and SARS-CoV-2 (Supplementary File S4) [37-39].

\subsection{Case Reports of Triple Infection with HIV, TB and SARS-CoV-2}

The detailed description of the five cases is depicted in Supplementary File S4, with their main characteristics shown in Table 1. Four out of the total five ones were published in American Journal of Tropical Medicine and Hygiene [38,39]. The cases reported were from Brazil $(n=2)$, Morocco $(n=1)$ and Panama $(n=2)$. It would have seemed reasonable to expect detailed series of triple infection cases from any Sub-Saharan country due to the high prevalence of HIV and TB coinfection, but we only found data from cohort studies, as we describe later.

As shown in Table 1, all cases except one were males, with an age range from 29 to 53 years. In addition, the clinical management and outcomes described for these patients could be considered similar to those with only COVID-19. The diagnosis of COVID-19 was coincident with the detection of the other infections in three out of the five cases. When HIV condition was previously known, there was not adherence to any antiretroviral therapy [38]. TB status was known in two patients, with a previous TB treatment including rifampicin and isoniazid for one of them [39], whereas no tuberculostatic was indicated for the other patient. When stated, the diagnosis of SARS-CoV-2 infection was performed by RT-PCR on nasopharyngeal exudates. 
Table 1. Main characteristics of the 5 triple-infection cases reported.

\begin{tabular}{|c|c|c|c|c|c|c|c|c|c|c|c|c|}
\hline Cases & Origin & $\begin{array}{c}\text { Age } \\
\text { (Years) }\end{array}$ & Gender & $\begin{array}{c}\text { HIV and } \\
\text { SARS-CoV-2 } \\
\text { Coincident } \\
\text { Diagnosis? } \\
\text { (Yes/No) }\end{array}$ & $\begin{array}{c}\text { AIDS- } \\
\text { Defining } \\
\text { Condition }\end{array}$ & $\begin{array}{c}\text { TB and } \\
\text { SARS-CoV-2 } \\
\text { Coincident } \\
\text { Diagnosis? } \\
\text { (Yes/No) }\end{array}$ & $\begin{array}{c}\text { Haematological } \\
\text { Abnormalities }\end{array}$ & $\begin{array}{l}\text { Biochemical } \\
\text { Assessment }\end{array}$ & $\begin{array}{c}\text { Exertional } \\
\text { Dyspnea }\end{array}$ & Fever & $\begin{array}{l}\text { Respiratory } \\
\text { Therapy } \\
\text { (Yes/No) }\end{array}$ & Reference \\
\hline 1 & Morocco & 32 & Female & Yes & No & Yes & $\begin{array}{c}\text { Thrombocytopenia } \\
\text { and leucopenia }\end{array}$ & $\begin{array}{l}\text { Anemia, hyper- } \\
\text { ferritinemia }\end{array}$ & Yes & Yes & No & [37] \\
\hline 2 & Brazil & 43 & Male & $\mathrm{No}^{\mathrm{a}}$ & Yes & Yes & $\begin{array}{l}\text { Lymphopenia, low } \\
\text { haemoglobin and } \\
\text { haematocrit levels }\end{array}$ & $\begin{array}{c}\text { Increase of } \\
\text { LDH and CRP }\end{array}$ & No & No & Not stated & [38] \\
\hline 3 & Brazil & 39 & Male & $\mathrm{No}^{\mathrm{a}}$ & Yes & No & $\begin{array}{l}\text { Lymphopenia, low } \\
\text { haemoglobin and } \\
\text { haematocrit levels }\end{array}$ & Increase of CRP & Mild & Yes & $\mathrm{No}^{b}$ & [38] \\
\hline 4 & Panama & 53 & Male & Yes & No & No & Not stated & Mild anemia & Moderate & Yes & Yes $^{c}$ & [39] \\
\hline 5 & Panama & 29 & Male & Yes & No & Yes & $\begin{array}{l}\text { Neutrophilia and } \\
\text { lymphopenia }\end{array}$ & $\begin{array}{l}\text { Mild anemia, } \\
\text { elevation of } \\
\text { CRP, ferritin, } \\
\text { D-dimer and } \\
\text { procalcitonin }\end{array}$ & Moderate & No & Yes & [39] \\
\hline
\end{tabular}


Regarding biochemical parameters assessment, three patients showed an elevation of C-reactive protein (CRP), the other three anemia and two of them a serum ferritin level above reference limits (Table 1). Lymphopenia was also found in all but one patient. Elevated CRP, lactate dehydrogenase and serum ferritin levels besides lymphopenia were previously established as predictors of COVID-19 severity and mortality (Table 1) [40-42]. However, respiratory support was needed in only half of cases [39]. Moreover, clinical management and therapy were not different from the ones used at early stage of the pandemic in the rest of countries: Hydroxychloroquine (HCQ) or chloroquine (CQ) associated with oral azithromycin. The potential use of azithromycin seemed to lay in its immunomodulatory effect as well as its ability to increase the effectiveness of HCQ in decreasing the viral load $[43,44]$. In addition, HCQ and CQ were proposed as treatment for COVID-19 also in the dawn of this pandemic, but recent clinical studies on COVID-19 patients treated with $\mathrm{CQ} / \mathrm{HCQ}$ and AZM led to controversial results because of their inefficacy and adverse side effects [45-47]. All the patients in the cases series reviewed were completely recovered though (Supplementary File S4) [37-39].

Finally, we would like to remark the thromboprophylaxis treatment in Rivas and collaborators' two cases with low molecular weight heparin [39]. COVID-19 severity and mortality were soon associated with an increment of prothrombotic parameters, particularly D-dimer levels [41,42]. Thus, anticoagulants were expected to be beneficial in mild and severe COVID-19 illness [48,49].

\subsection{Narrative Review Findings}

\subsubsection{General Overview}

The coinfection of SARS-CoV-2 and Mycobacterium tuberculosis in HIV patients was highlighted as a matter of concern for some researchers [50]. We found models simulating transmission scenarios for HIV and TB, which predicted an increase of up to $10 \%$ and $20 \%$, respectively, in high-burden settings compared with a non-COVID-19 situation [51]. However, reports describing cases which jointly captured these three concomitant infections, were anecdotal during last year, as already exposed in the previous section. Cohort studies were more abundant, such as an analysis carried out in Western Cape, South Africa, which showed an independent influence of HIV and TB on COVID-19 mortality [52].

Many authors appealed to elucidate the tangible influence of HIV and TB over COVID19 severity, since resources were often scarce, with intensive care facilities completely full so the admission of patients had to be rationed [53]. This need of a thorough research was especially claimed for children, who represented a significant percentage of hospitalization in low- and middle-income countries, in particular sub-Saharan African countries [54]. Some COVID-19 surveillance studies and systems designed with the aim of determining the impact of HIV and TB on SARS-CoV-2 infection susceptibility, were ongoing or not finished yet [55].

Basic research focused on this triple infection was also found, showing that molecular studies evidenced an increased expression of angiotensin-converting enzyme 2 (ACE2), the SARS-CoV-2 entry receptor, in HIV / TB co-infected patients, but this finding was only a tissue level result [56]. Other authors pointed out a shared correlation between hijacking the endo-lysosomal system and the pathogenesis of the three microorganisms [57].

Despite the few targeted clinical and basic approaches retrieved in our literature search, the findings often spotlighted the social impact and public health consequences of the COVID-19 pandemic on the landscape of HIV and TB patients, so we have dedicated a specific section at the end of the Results section.

\subsubsection{Dual Infection Scenario (Either HIV or MTB with SARS-CoV-2)}

Co-infection of SARS-CoV-2, either with HIV or MTB, was more common in literature. Regarding HIV co-infection, there existed an adequate evidence to challenge if PLWHIV were at higher risk of contracting SARS-CoV-2, as firstly speculated, or not. Some immunological features were shared by both viral infections. The acute phase of HIV infection 
was characterized by an important decline of CD4+ T cell count that persistently remained during chronic phase, leading to the well-known lymphopenia observed in untreated patients with AIDS. On the other hand, a poor clinical outcome of COVID-19 also related to lymphopenia due to the suppression of B lymphocytes, and helper (CD4+) and cytotoxic (CD8+) T cell disfunction [29,31,40,58,59].

In addition, HIV-positive persons usually presented comorbidities linked to risk factors for severity of COVID-19 symptoms, such as cardiovascular disease, diabetes and hypertension [60-63]. Smoking was also pointed out as a factor contributing to the higher prevalence and mortality in the current COVID-19 pandemic, and even in other infectious diseases, such as HIV and TB themselves [64]. Ageing of PLWHIV, as positive long-term result of ART, might become another risky feature for COVID-19 in these patients $[40,65,66]$. However, clinical case series reported worldwide during the earlier stage of the COVID-19 pandemic (first semester of 2020) showed a similar disease severity, with HIV patients admitted to intensive care and then discharged alive, in a comparable percentage of the general population [66-77]. This similar situation appeared even when HIV infection was not well controlled and patients presented a prior AIDS-defining event [72,78].

Furthermore, the so-called cytokine storm in patients with COVID-19 was related to severity, as already demonstrated in similar diseases, like SARS and Middle East respiratory syndrome (MERS) [79-83]. Thus, some researchers emphasized on ways to avoid the overproduction of these inflammatory mediators in order to reduce the damage and improve COVID-19 outcomes [82]. In that line, HIV infection was associated with a persistent immune disruption, even despite an effective ART, so such dysregulation could paradoxically prevent the mentioned cytokine release in severe and critical COVID-19 [84,85].

ART was also hypothesized as the reason of the lack of an increased risk for serious COVID-19 among HIV-positive persons. However, the findings were contradictory. HIV-positive patients receiving tenofovir-based ARTs were found to have a lower risk of hospitalization related to severe COVID-19 than those receiving other therapies [52,66], whereas other authors ruled out the possibility of a protective effect of tenofovir or any other antiretroviral therapy $[70,78,86]$.

As the pandemic progressed, more data about HIV-positive patients became available and the equal risk perceived in HIV- and SARS-CoV-2 coinfected individuals was turning around a misperception. The key predictors for poor outcomes of COVID-19 mentioned (i.e., age and comorbidities) in the dual viral infection remained being the same ones as seen for SARS-CoV-2 exclusive infection $[68,87,88]$. Nevertheless, in the light of new research arose, advanced immunodeficiency and uncontrolled HIV-infection, previously underestimated as risk factors by some studies [72], were now well established as possible determinants of severity of COVID-19, showing increased rates of hospitalization and death $[52,89,90]$. Furthermore, lymphopenia in severe COVID-19 was prognostic of poor outcomes $[26,42]$, so it would be logical to assume that immunodeficiency (defined as CD4 count $<350 / \mu \mathrm{L}$ ) during admission in PLWH was associated with COVID-19 death. Special mention to Hoffmann and collaborators' study who did not find any significant association between severity of COVID-19 and a detectable HIV RNA, a prior AIDS-defining illness or TDF, as we mentioned before, but they did find it for a CD4+ T cell nadir of $<200 / \mu \mathrm{L}$ and a current CD4+ T cells count $<350 / \mu \mathrm{L}$ [78].

Boulle and collaborators performed a large-scale population cohort study in Western Cape, South Africa, finding a two-fold and almost a three-fold increased risk of mortality from COVID-19 for patients coinfected with HIV and active TB, respectively [52]. In PLWH, this greater risk was found even in patients aged younger than 50 years and independently of their viral suppression [52]. However, a high prevalence of comorbidities in deceased PLWH could be acting as a confounding factor [52]. Another study came to similar conclusions with regards to COVID-19 mortality and comorbidities in HIV and/or TB co-infected population: HIV, TB or both diseases were highlighted not to be the most common risk factors in comparison to older age and other comorbidities, such as diabetes and hypertension, in individuals dying from COVID-19 [91]. Nevertheless, 
HIV-infected individuals should not be considered to be protected from severe COVID-19. They must receive the same therapeutic approach applied to general population, and even be prioritized SARS-CoV-2 vaccination $[77,90]$.

On the other hand, when considering TB-SARS-CoV-2 coinfection, it seemed evident that environmental conditions surrounding people who suffered most from TB were the best breeding ground for them to also be affected by the COVID-19 pandemic [92]. In addition, both TB and COVID-19 were respiratory infections, transmitted mainly by close contacts, and with similar symptoms. They might interplay reciprocally, but they were quite different: $\mathrm{TB}$ could be a chronic disease with patients coughing for a minimum of a couple of weeks, whereas COVID-19 had a quick onset. A differential diagnosis between both infections was possible and simple when healthcare providers were well-trained [34].

COVID-19 pneumonia may contribute to TB progression, whereas pulmonary TB impact the lungs' function, so co-infection with SARS-CoV-2 might worsen COVID-19 prognosis itself. Tuberculosis could intensify COVID-19 by two hypothesized ways: impairing immune responses and increasing angiotensin converting enzyme 2 receptor expression in respiratory epithelial cells [58]. A meta-analysis performed by Tamuzi and collaborators found that TB was a risk factor for COVID-19 severity and even mortality, regardless HIV status [93]. However, case series did not report any contribution of COVID-19 to TB pathogenesis, so their reciprocal influence could not be excluded or confirmed [94,95].

When combining environmental and pathogenic issues, studies reported a higher expected probability of long-term effects of the pandemic in people with TB, TB-HIV coinfection or chronic lung disease [96]. A recent meta-analysis considering dual infection, either TB and HIV, showed an increased risk of mortality for the former, but a comparable clinical outcome of COVID-19 in patients with or without this latter infection [97]. Similarly, another study in Nigeria pointed to a higher mortality rate in states with high TB prevalence (with a weak association though), and the opposite finding for HIV infection: a negative correlation between HIV prevalence and COVID-19 mortality [98]. However, other reviews, even those aimed at children, did not find a significant risk factor for severe COVID19 in pre-existing respiratory diseases [99]. Furthermore, our collection of specific case series after the literature review (Supplementary File S4), did not show any significant difference at clinical management or future scenario of healing. In four out of five cases, the clinical assessments to investigate COVID-19 facilitated the identification of pre-existing TB and/or HIV. HIV and TB co-infection was known but uncontrolled in only one case [38] In addition, both infections were previously unidentified and simultaneously diagnosed in two out of all cases [37,39].

Nevertheless, the achievement of a considerable body of evidence for TB and HIV pre-existing conditions as determinants to predict COVID-19 progression would require the design of a research protocol a priori considering them, like Allwood and collaborators proposed [100]. Particular focus should be on how COVID-19 differently manifested among women with HIV and/or TB, endemic in Sub-Saharian African countries and so, a high infections burden setting [101].

\subsubsection{Social and Public Health Implications in the Context of the COVID-19 Pandemic}

Most of our literature findings also warned about the impact of COVID-19 pandemic over the diagnosis, healthcare, drug supply, and even research about patients affected by any or both other two infections [102]. The current pandemic could lead to an amplification of the existing health inequities, especially concerning already marginalized communities, racial/ethnic minorities, women, and children [103-106]. The most dramatic influence would obviously be observed in low- and middle-income countries, already ravaged by TB and HIV epidemics $[33,34,36]$. When the majority of developed world was already immersed in COVID-19 vaccine rollout, some voices were pleading in favour of a global health equity and justice to achieve a factual end of this pandemic [107]. Vaccination in countries with a significant burden of the HIV and TB co-infections must be done guaranteeing safety and efficacy of available vaccines, besides affordable cost and manufacturing 
infrastructure. Addressing the first issue of safety, immunocompromised individuals should only be vaccinated with certain vaccine modalities, different from live-attenuated or replicating vaccines; regarding vaccine efficacy, the magnitude and durability of immunity in such patients were up to date unknown [108].

One of the first issues threatened by the pandemic was the diagnosis for both TB and HIV infections, since their diagnostic platforms, i.e., GeneXpert and PCR, were devoted to COVID-19 tests $[33,109,110]$. Furthermore, the rigid lockdowns enforced in many countries like South Africa, emulating the first Chinese mitigation strategies, also jeopardized HIV and TB care services $[35,111]$. So, a six-month disruption of ART in PLWHIV was estimated by WHO and other researchers to lead to a substantial excess of mortality due to AIDSrelated conditions, such as TB itself $[51,112]$. Even though the drug supply was assured during the current COVID-19 pandemic, the fear of being exposed to SARS-CoV-2 infection or the difficult of commuting (many HIV and TB patients relied on public transportation) halted the normal access to health point of care or disrupted the routinely attendance to clinics $[33,111,113]$.

At this time with three ongoing epidemics, some authors have suggested key adaptations to ensure delivery of healthcare services while reducing the risks of SARS-CoV-2 exposure in high HIV/TB burden settings. Take, for instance, any situation avoiding unnecessary visits, such as a common starting treatment day in HIV-TB co-infected patients, if any of the infections were diagnosed but not treated yet; providing sufficient TB and/or HIV treatment; or limiting in-person interactions with health care workers to clinical assessments at the completion of treatment or with urgent results (e.g., positive serum cryptococcal antigen test, drug resistances, etc.). Other consultations should be done telephonically [114].

Another dramatic consequence that the ongoing COVID-19 pandemic might cause over TB and HIV infections (and extensively over other infectious diseases) was represented by the delay and even the dropout of new approaches to fighting against drug resistance [102]. A successful completion of any treatment was compromised as we discussed before, with a special impact on pediatric age groups [104,115].

However, not all the measures to prevent COVID-19 had led to a deterioration of TB and HIV policies. For instance, wearing a surgical mask might reduce the transmission of TB [116]. In addition, we observed an acceleration of scientific and innovation approaches (new treatment, cutting-edge vaccines, etc.). However, some authors put the spotlight in global funding models and in international diplomacy in order to distribute those achievements equally, always avoiding the disruption of essential healthcare services $[117,118]$.

\section{Conclusions}

We need more thoroughly observational and cohort studies whose design deliberately embraces the triple infection as a priori inclusion criterion in the target population. Only then, we will be able to confirm the influence on clinical evolution, management, therapy and outcomes of COVID-19 patients with HIV and TB infections. At the moment, the main concern is the continuity of all essential services for HIV / AIDS and TB patients. Most of them have been achieved after arduous effort, especially in many developing countries where they are currently and seriously being threatened.

Supplementary Materials: The following are available online at https:/ / www.mdpi.com/article/10 .3390/v13050931/s1, Supplementary File S1: Publications retrieved in our literature search, Supplementary File S2: Studies discarded from the original literature search, Supplementary File S3: Studies that met the inclusion criteria, Supplementary File S4: Case_series: Case reports found.

Funding: This research received no external funding.

Conflicts of Interest: The authors declare no conflict of interest. 


\section{References}

1. UNAIDS. Global HIV \& AIDS Statistics-2020 Fact Sheet. Global HIV Statistics. Available online: https://www.unaids.org/en/ resources / fact-sheet (accessed on 21 January 2021).

2. Doitsh, G.; Galloway, N.L.K.; Geng, X.; Yang, Z.; Monroe, K.M.; Zepeda, O.; Hunt, P.W.; Hatano, H.; Sowinski, S.; Muñoz-Arias, I.; et al. Cell death by pyroptosis drives CD4 T-cell depletion in HIV-1 infection. Nature 2014, 505, 509-514. [CrossRef]

3. Zhang, Q.; Frange, P.; Blanche, S.; Casanova, J.L. Pathogenesis of infections in HIV-infected individuals: Insights from primary immunodeficiencies. Curr. Opin. Immunol. 2017, 48, 122-133. [CrossRef]

4. Ghosn, J.; Taiwo, B.; Seedat, S.; Autran, B.; Katlama, C. HIV. Lancet 2018, 392, 685-697. [CrossRef]

5. Centers for Disease Control and Prevention (CDC). Epidemiology of HIV/AIDS-United States, 1981-2005. MMWR Morb. Mortal Wkly. Rep. 2006, 55, 589-592.

6. Marcus, J.L.; Chao, C.R.; Leyden, W.A.; Xu, L.; Quesenberry, C.P., Jr.; Klein, D.B.; Towner, W.J.; Horberg, M.A.; Silverberg, M.J Narrowing the Gap in Life Expectancy Between HIV-Infected and HIV-Uninfected Individuals with Access to Care. J. Acquir. Immune Defic. Syndr. 2016, 73, 39-46. [CrossRef] [PubMed]

7. Marcus, J.L.; Leyden, W.A.; Alexeeff, S.E.; Anderson, A.N.; Hechter, R.C.; Hu, H.; Lam, J.O.; Towner, W.J.; Yuan, Q.; Horberg, M.A.; et al. Comparison of Overall and Comorbidity-Free Life Expectancy Between Insured Adults with and without HIV Infection, 2000-2016. JAMA Netw. Open. 2020, 3, e207954. [CrossRef]

8. Teeraananchai, S.; Kerr, S.J.; Amin, J.; Ruxrungtham, K.; Law, M.G. Life expectancy of HIV-positive people after starting combination antiretroviral therapy: A meta-analysis. HIV Med. 2017, 18, 256-266. [CrossRef]

9. Ruelas, D.S.; Greene, W.C. An integrated overview of HIV-1 latency. Cell 2013, 155, 519-529. [CrossRef]

10. Romani, B.; Allahbakhshi, E. Underlying mechanisms of HIV-1 latency. Virus Genes 2017, 53, 329-339. [CrossRef]

11. Ventura, J.D. Human Immunodeficiency Virus 1 (HIV-1): Viral Latency, the Reservoir, and the Cure. Yale J. Biol Med. 2020, 93, 549-560.

12. Cribbs, S.K.; Crothers, K.; Morris, A. Pathogenesis of HIV-Related Lung Disease: Immunity, Infection, and Inflammation. Physiol. Rev. 2020, 100, 603-632. [CrossRef] [PubMed]

13. Dheda, K.; Barry, C.E.; Maartens, G. Tuberculosis. Lancet 2016, 387, 1211-1226. [CrossRef]

14. Pai, M.; Behr, M.A.; Dowdy, D.; Dheda, K.; Divangahi, M.; Boehme, C.C.; Ginsberg, A.; Swaminathan, S.; Spigelman, M.; Getahun, H.; et al. Tuberculosis. Nat. Rev. Dis Primers 2016, 2, 16076. [CrossRef] [PubMed]

15. World Health Organization (WHO). Tuberculosis; 14 October 2020: World Health Organization. 2020. Available online: https://www.who.int/news-room/fact-sheets/detail/tuberculosis (accessed on 12 March 2021).

16. Sotgiu, G.; Falzon, D.; Hollo, V.; Ködmön, C.; Lefebvre, N.; Dadu, A.; van der Merf, M. Determinants of site of tuberculosis disease: An analysis of European surveillance data from 2003 to 2014. PLoS ONE 2017, 12, e0186499. [CrossRef] [PubMed]

17. Eddabra, R.; Neffa, M. Epidemiological profile among pulmonary and extrapulmonary tuberculosis patients in Laayoune, Morocco. Pan. Afr. Med. J. 2020, 37, 56. [CrossRef]

18. Ossalé Abacka, K.B.; Koné, A.; Akoli Ekoya, O.; Bopaka, R.G.; Lankoandé Siri, H.; Horo, K. Extrapulmonary tuberculosis versus pulmonary tuberculosis: Epidemiological, diagnosis and evolutive aspects. Rev. Pneumol. Clin. 2018, 74, 452-457. [CrossRef]

19. Zhu, N.; Zhang, D.; Wang, W.; Li, X.; Yang, B.; Song, J.; Zhao, X.; Huang, B.; Shi, W.; Lu, R.; et al. A novel coronavirus from patients with pneumonia in China, 2019. N. Engl. J. Med. 2020, 382, 727-733. [CrossRef]

20. Chan, J.F.; Kok, K.H.; Zhu, Z.; Chu, H.; To, K.K.; Yuan, S.; Yuen, K.-Y. Genomic characterization of the 2019 novel humanpathogenic coronavirus isolated from a patient with atypical pneumonia after visiting Wuhan. Emerg. Microbes Infect. 2020, 9 , 221-236. [CrossRef]

21. Wu, F.; Zhao, S.; Yu, B.; Chen, Y.M.; Wang, W.; Song, Z.G.; Hu, Y.; Tao, Z.-W.; Tian, J.-H.; Pei, Y.-Y.; et al. A new coronavirus associated with human respiratory disease in China. Nature 2020, 579, 265-269. [CrossRef]

22. Dong, E.; Du, H.; Gardner, L. An interactive web-based dashboard to track COVID-19 in real time. Lancet Infect. Dis. 2020, 20, 533-534. [CrossRef]

23. Morawska, L.; Cao, J. Airborne transmission of SARS-CoV-2: The world should face the reality. Environ. Int. 2020, 139, 105730. [CrossRef]

24. Vivanti, A.J.; Vauloup-Fellous, C.; Prevot, S.; Zupan, V.; Suffee, C.; Do Cao, J.; Benachi, A.; de Luca, D. Transplacental transmission of SARS-CoV-2 infection. Nat. Commun. 2020, 11, 3572. [CrossRef] [PubMed]

25. Liu, Z.; Long, W.; Tu, M.; Chen, S.; Huang, Y.; Wang, S.; Zhou, W.; Chen, D.; Zhou, L.; Wang, M.; et al. Lymphocyte subset (CD4+, CD8+) counts reflect the severity of infection and predict the clinical outcomes in patients with COVID-19. J. Infect. 2020, 81, 318-356. [CrossRef]

26. Tan, L.; Wang, Q.; Zhang, D.; Ding, J.; Huang, Q.; Tang, Y.Q.; Wang, Q.; Miao, H. Lymphopenia predicts disease severity of COVID-19: A descriptive and predictive study. Signal. Transduct. Target. Ther. 2020, 5, 33. [CrossRef] [PubMed]

27. Qin, C.; Zhou, L.; Hu, Z.; Zhang, S.; Yang, S.; Tao, Y.; Xie, C.; Ma, K.; Shang, K.; Wang, W.; et al. Dysregulation of immune response in patients with COVID-19 in Wuhan, China. Clin. Infect. Dis. 2020, 71, 762-768. [CrossRef]

28. Xu, B.; Fan, C.Y.; Wang, A.L.; Zou, Y.L.; Yu, Y.H.; He, C.; Xia, W.-G.; Zhang, J.-X.; Miao, Q. Suppressed T cell-mediated immunity in patients with COVID-19: A clinical retrospective study in Wuhan, China. J. Infect. 2020, 81, e51-e60. [CrossRef] 
29. Wan, S.; Yi, Q.; Fan, S.; Lv, J.; Zhang, X.; Guo, L.; Lang, C.; Xiao, Q.; Xiao, K.; Yi, Z.; et al. Relationships among lymphocyte subsets, cytokines, and the pulmonary inflammation index in coronavirus (COVID-19) infected patients. Br. J. Haematol. 2020, 189, 428-437. [CrossRef] [PubMed]

30. Wang, F.; Nie, J.; Wang, H.; Zhao, Q.; Xiong, Y.; Deng, L.; Song, S.; Ma, Z.; Mo, P.; Zhang, Y. Characteristics of peripheral lymphocyte subset alteration in COVID-19 pneumonia. J. Infect. Dis. 2020, 221, 1762-1769. [CrossRef] [PubMed]

31. Zhou, Y.; Zhang, Z.; Tian, J.; Xiong, S. Risk factors associated with disease progression in a cohort of patients infected with the 2019 novel coronavirus. Ann. Palliat. Med. 2020, 9, 428-436. [CrossRef]

32. Peng, X.; Ouyang, J.; Isnard, S.; Lin, J.; Fombuena, B.; Zhu, B.; Routy, J.-P. Sharing CD4+ T Cell Loss: When COVID-19 and HIV Collide on Immune System. Front. Immunol. 2020, 11, 596631. [CrossRef]

33. Karim, Q.A.; Karim, S.S.A. COVID-19 affects HIV and tuberculosis care. Science 2020, 369, 366-368. [CrossRef]

34. Adepoju, P. Tuberculosis and HIV responses threatened by COVID-19. Lancet HIV 2020, 7, e319-e320. [CrossRef]

35. Boffa, J.; Mhlaba, T.; Sulis, G.; Moyo, S.; Sifumba, Z.; Pai, M.; Daftary, A. COVID-19 and tuberculosis in South Africa: A dangerous combination. S. Afr. Med. J. 2020, 110, 341-342. [CrossRef] [PubMed]

36. Nordling, L. Tested by HIV and TB, South Africa confronts new pandemic. Science 2020, 368, 117. [CrossRef] [PubMed]

37. Bouaré, F.; Laghmari, M.; Etouche, F.N.; Arjdal, B.; Saidi, I.; Hajhouji, F.; Ghannane, H.; Amro, L.; Tassi, N.; Benali, S.A. Unusual association of COVID-19, pulmonary tuberculosis and human immunodeficiency virus, having progressed favorably under treatment with chloroquine and rifampin. Pan. Afr. Med. J. 2020, 35 (Suppl. S2), 110. [CrossRef]

38. Farias, L.A.B.G.; Moreira, A.L.G.; Corrêa, E.A.; de Oliveira Lima, C.A.L.; Lopes, I.M.P.; de Holanda, P.E.L.; Nunes, F.R.; Neto, R.D.J.P. Case Report: Coronavirus Disease and Pulmonary Tuberculosis in Patients with Human Immunodeficiency Virus: Report of Two Cases. Am. J. Trop. Med. Hyg. 2020, 103, 1593-1596. [CrossRef]

39. Rivas, N.; Espinoza, M.; Loban, A.; Luque, O.; Jurado, J.; Henry-Hurtado, N.; Goodridge, A. Case Report: COVID-19 Recovery from Triple Infection with Mycobacterium tuberculosis, HIV, and SARS-CoV-2. Am. J. Trop. Med. Hyg. 2020, 103, 1597-1599. [CrossRef]

40. Chen, Y.; Klein, S.L.; Garibaldi, B.T.; Li, H.; Wu, C.; Osevala, N.M.; Li, T.; Margolick, J.B.; Pawelec, G.; Leng, S.X. Aging in COVID-19: Vulnerability, immunity and intervention. Ageing Res. Rev. 2021, 65, 101205. [CrossRef]

41. Chen, Z.; Zhang, F.; Hu, W.; Chen, Q.; Li, C.; Wu, L.; Zhang, Z.; Li, B.; Ye, Q.; Mei, J.; et al. Laboratory markers associated with COVID-19 progression in patients with or without comorbidity: A retrospective study. J. Clin. Lab. Anal. 2021, 35, e23644. [CrossRef]

42. Ramadan, H.K.; Mahmoud, M.A.; Aburahma, M.Z.; Elkhawaga, A.A.; El-Mokhtar, M.A.; Sayed, I.M.; Hosni, A.; Hassany, S.M.; Medhat, M.A. Predictors of Severity and Co-Infection Resistance Profile in COVID-19 Patients: First Report from Upper Egypt. Infect. Drug Resist. 2020, 13, 3409-3422. [CrossRef]

43. Gautret, P.; Lagier, J.C.; Parola, P.; Hoang, V.T.; Meddeb, L.; Mailhe, M.; Doudier, B.; Courjon, J.; Giordanengo, V.; Vieira, V.E.; et al. Hydroxychloroquine and azithromycin as a treatment of COVID-19: Results of an open-label non-randomized clinical trial. Int. J. Antimicrob. Agents 2020, 56, 105949. [CrossRef] [PubMed]

44. Weng, D.; Wu, Q.; Chen, X.Q.; Du, Y.K.; Chen, T.; Li, H.; Tang, D.-L.; Li, Q.-H.; Zhang, Y.; Lu, L.-Q.; et al. Azithromycin treats diffuse panbronchiolitis by targeting T cells via inhibition of mTOR pathway. Biomed. Pharmacother. 2019, 110, 440-448. [CrossRef]

45. Mitjà, O.; Corbacho-Monné, M.; Ubals, M.; Alemany, A.; Suñer, C.; Tebé, C.; Tobias, A.; Peñafiel, J.; Ballana, E.; Pérez, C.A.; et al. A Cluster-Randomized Trial of Hydroxychloroquine for Prevention of Covid-19. N. Engl. J. Med. 2021, 384, 417-427. [CrossRef] [PubMed]

46. Horby, P.; Mafham, M.; Linsell, L.; Bell, J.L.; Staplin, N.; Emberson, J.R.; Wiselka, M.; Ustianowski, A.; Elmahi, E.; Prudon, B.; et al. Effect of Hydroxychloroquine in Hospitalized Patients with Covid-19. N. Engl. J. Med. 2020, 383, 2030-2040.

47. RECOVERY Collaborative Group. Azithromycin in patients admitted to hospital with COVID-19 (RECOVERY): A randomised, controlled, open-label, platform trial. Lancet 2021, 397, 605-612. [CrossRef]

48. Billett, H.H.; Reyes-Gil, M.; Szymanski, J.; Ikemura, K.; Stahl, L.R.; Lo, Y.; Rahman, S.; Gonzalez-Lugo, J.D.; Kushnir, M.; Barouqa, M.; et al. Anticoagulation in COVID-19: Effect of Enoxaparin, Heparin, and Apixaban on Mortality. Thromb. Haemost. 2020, 120, 1691-1699. [PubMed]

49. Rentsch, C.T.; Beckman, J.A.; Tomlinson, L.; Gellad, W.F.; Alcorn, C.; Kidwai-Khan, F.; Skanderson, M.; Brittain, E.; King, J.T.; Ho, Y.-L.; et al. Early initiation of prophylactic anticoagulation for prevention of coronavirus disease 2019 mortality in patients admitted to hospital in the United States: Cohort study. BMJ 2021, 372, n311. [CrossRef]

50. Kay, A.W.; Ness, T.E.; Martinez, L.; Mandalakas, A.M. It Ain't Over Till It's Over: The Triple Threat of COVID-19, TB, and HIV. Am. J. Trop. Med. Hyg. 2020, 103, 1348-1349. [CrossRef]

51. Hogan, A.B.; Jewell, B.L.; Sherrard-Smith, E.; Vesga, J.F.; Watson, O.J.; Whittaker, C.; Hamlet, A.; Smith, J.A.; Winskill, P.; Verity, R.; et al. Potential impact of the COVID-19 pandemic on HIV, tuberculosis, and malaria in low-income and middle-income countries: A modelling study. Lancet Glob. Health 2020, 8, e1132-e1141. [CrossRef]

52. Boulle, A.; Davies, M.A.; Hussey, H.; Ismail, M.; Morden, E.; Vundle, Z.; Zweingethal, V.; Mahomed, H.; Paleker, M.; Pienaar, D.; et al. Risk factors for COVID-19 death in a population cohort study from the Western Cape Province, South Africa. Clin. Infect. Dis. 2020, ciaa1198. [CrossRef]

53. Rossouw, T.M.; Boswell, M.T.; Nienaber, A.G.; Moodley, K. Comorbidity in context: Part 1. Medical considerations around HIV and tuberculosis during the COVID-19 pandemic in South Africa. S. Afr. Med. J. 2020, 110, 621-624. 
54. Van der Zalm, M.M.; Lishman, J.; Verhagen, L.M.; Redfern, A.; Smit, L.; Barday, M.; Ruttens, D.; Da Costa, A.; van Jaarsveld, S.; Itana, J.; et al. Clinical experience with SARS CoV-2 related illness in children-hospital experience in Cape Town, South Africa. Clin. Infect. Dis. 2020, ciaa1666. [CrossRef] [PubMed]

55. Siedner, M.J.; Harling, G.; Derache, A.; Smit, T.; Khoza, T.; Gunda, R.; Mngomezulu, T.; Gareta, D.; Majozi, N.; Ehlers, E.; et al. Protocol: Leveraging a demographic and health surveillance system for Covid-19 Surveillance in rural KwaZulu-Natal. Wellcome Open Res. 2020, 5, 109. [CrossRef]

56. Ziegler, C.G.K.; Allon, S.J.; Nyquist, S.K.; Mbano, I.M.; Miao, V.N.; Tzouanas, C.N.; Cao, Y.; Yousif, A.S.; Bals, J.; Hauser, B.M.; et al. SARS-CoV-2 Receptor ACE2 is an Interferon-Stimulated Gene in Human Airway Epithelial Cells and is Detected in Specific Cell Subsets across Tissues. Cell 2020, 181, 1016-1035. [CrossRef]

57. Chao, Y.K.; Chang, S.Y.; Grimm, C. Endo-Lysosomal Cation Channels and Infectious Diseases. Rev. Physiol. Biochem. Pharmacol. 2020, 1-18. [CrossRef]

58. Liu, Y.; Bi, L.; Chen, Y.; Wang, Y.; Fleming, J.; Yu, Y.; Gu, Y.; Liu, C.; Fan, L.; Wang, X.; et al. Active or latent tuberculosis increases susceptibility to COVID-19 and disease severity. medRxiv 2020. [CrossRef]

59. Zheng, H.Y.; Zhang, M.; Yang, C.X.; Zhang, N.; Wang, X.C.; Yang, X.P.; Dong, X.Q.; Zheng, Y.T. Elevated exhaustion levels and reduced functional diversity of $\mathrm{T}$ cells in peripheral blood may predict severe progression in COVID-19 patients. Cell Mol. Immunol. 2020, 17, 541-543. [CrossRef] [PubMed]

60. Hu, L.; Chen, S.; Fu, Y.; Gao, Z.; Long, H.; Ren, H.W.; Zuo, Y.; Wang, J.; Li, H.; Xu, Q.B.; et al. Risk Factors Associated with Clinical Outcomes in 323 Coronavirus Disease 2019 (COVID-19) Hospitalized Patients in Wuhan, China. Clin. Infect. Dis. 2020, 71, 2089-2098. [CrossRef]

61. Li, X.; Wang, L.; Yan, S.; Yang, F.; Xiang, L.; Zhu, J.; Shen, B.; Gong, Z. Clinical characteristics of 25 death cases with COVID-19: A retrospective review of medical records in a single medical center, Wuhan, China. Int. J. Infect. Dis. 2020, 94, 128-132. [CrossRef]

62. Richardson, S.; Hirsch, J.S.; Narasimhan, M.; Crawford, J.M.; McGinn, T.; Davidson, K.W.; the Northwell COVID-19 Research Consortium; Barnaby, D.P.; Becker, L.B.; Chelico, J.D.; et al. Presenting Characteristics, Comorbidities, and Outcomes Among 5700 Patients Hospitalized with COVID-19 in the New York City Area. JAMA 2020, 323, 2052-2059. [CrossRef]

63. World Health Organization (WHO). Clinical Management of Severe Acute Respiratory Infection (SARI) When COVID-19 Disease Is Suspected: Interim Guidance, 27 May 2020; World Health Organization: Genève, Switzerland, 2020. Available online: https: //www.who.int/publications/i/item/clinical-management-of-covid-19 (accessed on 17 February 2021).

64. Jiang, C.; Chen, Q.; Xie, M. Smoking increases the risk of infectious diseases: A narrative review. Tob. Induc. Dis. 2020, 18, 60. [CrossRef]

65. Lauc, G.; Sinclair, D. Biomarkers of biological age as predictors of COVID-19 disease severity. Aging 2020, 12, 6490-6491. [CrossRef] [PubMed]

66. Del Amo, J.; Polo, R.; Moreno, S.; Díaz, A.; Martínez, E.; Arribas, J.R.; Jarrín, I.; Hernán, M.A.; The Spanish HIV/COVID-19 Collaboration. Incidence and Severity of COVID-19 in HIV-Positive Persons Receiving Antiretroviral Therapy: A Cohort Study. Ann. Intern. Med. 2020, 173, 536-541. [CrossRef] [PubMed]

67. Blanco, J.L.; Ambrosioni, J.; Garcia, F.; Martínez, E.; Soriano, A.; Mallolas, J.; Miro, J.M.; COVID-19 in HIV Investigators. COVID-19 in patients with HIV: Clinical case series. Lancet HIV 2020, 7, e314-e316. [CrossRef]

68. Cabello, A.; Zamarro, B.; Nistal, S.; Victor, V.; Hernández, J.; Prieto-Pérez, L.; Carrillo, I.; Álvarez, B.; Fernández-Roblas, R.; Hernández-Segurado, M.; et al. COVID-19 in people living with HIV: A multicenter case-series study. Int. J. Infect. Dis. 2020, 102, 310-315. [CrossRef]

69. Gervasoni, C.; Meraviglia, P.; Riva, A.; Giacomelli, A.; Oreni, L.; Minisci, D.; Atzori, C.; Ridolfo, A.; Cattaneo, D. Clinical features and outcomes of HIV patients with coronavirus disease 2019. Clin. Infect Dis. 2020, 71, 2276-2278. [CrossRef] [PubMed]

70. Inciarte, A.; Gonzalez-Cordon, A.; Rojas, J.; Torres, B.; de Lazzari, E.; de la Mora, L.; Martinez-Rebollar, M.; Laguno, M.; Callau, P.; Gonzalez-Navarro, A.; et al. Clinical characteristics, risk factors, and incidence of symptomatic coronavirus disease 2019 in a large cohort of adults living with HIV: A single-center, prospective observational study. AIDS 2020, 34, 1775-1780. [CrossRef] [PubMed]

71. Karmen-Tuohy, S.; Carlucci, P.M.; Zacharioudakis, I.M.; Zervou, F.N.; Rebick, G.; Klein, E.; Reich, J.; Jones, S.; Rahimian, J. Outcomes among HIV-positive patients hospitalized with COVID-19. J. Acquir. Immune Defic. Syndr. 2020, 85, 6-10. [CrossRef]

72. Nagarakanti, S.R.; Okoh, A.K.; Grinberg, S.; Bishburg, E. Clinical outcomes of patients with COVID-19 and HIV coinfection. J. Med. Virol. 2021, 93, 1687-1693. [CrossRef]

73. Parker, A.; Koegelenberg, C.F.N.; Moolla, M.S.; Louw, E.H.; Mowlana, A.; Nortjé, A.; Ahmed, R.; Brittain, N.; Lalla, U.; Allwood, B.W.; et al. High HIV prevalence in an early cohort of hospital admissions with COVID-19 in Cape Town, South Africa. S. Afr. Med. J. 2020, 110, 982-987. [CrossRef]

74. Shalev, N.; Scherer, M.; LaSota, E.D.; Antoniou, P.; Yin, M.T.; Zucker, J.; Sobieszczyk, M.E. Clinical Characteristics and Outcomes in People Living with Human Immunodeficiency Virus Hospitalized for Coronavirus Disease 2019. Clin. Infect. Dis. 2020, 71, 2294-2297. [CrossRef]

75. Sigel, K.; Swartz, T.; Golden, E.; Paranjpe, I.; Somani, S.; Richter, F.; De Freitas, J.K.; Miotto, R.; Zhao, S.; Polak, P.; et al. Coronavirus 2019 and People Living with Human Immunodeficiency Virus: Outcomes for Hospitalized Patients in New York City. Clin. Infect. Dis. 2020, 71, 2933-2938. [CrossRef] [PubMed] 
76. Stoeckle, K.; Johnston, C.D.; Jannat-Khah, D.P.; Williams, S.C.; Ellman, T.M.; Vogler, M.A.; Gulick, R.M.; Glesby, M.J.; Choi, J.J. COVID-19 in Hospitalized Adults with HIV. Open Forum Infect. Dis. 2020, 7, ofaa327. [CrossRef]

77. Vizcarra, P.; Pérez-Elías, M.J.; Quereda, C.; Moreno, A.; Vivancos, M.J.; Dronda, F.; Casado, J.L.; COVID-19 ID Team. Description of COVID-19 in HIV-infected individuals: A single-centre, prospective cohort. Lancet HIV 2020, 7, e554-e564. [CrossRef]

78. Hoffmann, C.; Casado, J.L.; Härter, G.; Vizcarra, P.; Moreno, A.; Cattaneo, D.; Meraviglia, P.; Spinner, C.D.; Schabaz, F.; Grunwald S.; et al. Immune deficiency is a risk factor for severe COVID-19 in people living with HIV. HIV Med. 2021, 22, 372-378. [CrossRef]

79. Channappanavar, R.; Perlman, S. Pathogenic human coronavirus infections: Causes and consequences of cytokine storm and immunopathology. Semin. Immunopathol. 2017, 39, 529-539. [CrossRef]

80. Lau, S.K.P.; Lau, C.C.Y.; Chan, K.H.; Li, C.P.Y.; Chen, H.; Jin, D.Y.; Chan, J.F.W.; Woo, P.C.Y.; Yuen, K.Y. Delayed induction of proinflammatory cytokines and suppression of innate antiviral response by the novel Middle East respiratory syndrome coronavirus: Implications for pathogenesis and treatment. J. Gen. Virol. 2013, 94, 2679-2690. [CrossRef]

81. Moore, J.B.; June, C.H. Cytokine release syndrome in severe COVID-19. Science 2020, 368, 473-474. [CrossRef] [PubMed]

82. Safari, S.; Salimi, A.; Zali, A.; Jahangirifard, A.; Bastanhagh, E.; Aminnejad, R.; Dabbagh, A.; Lotfi, A.H.; Saeidi, M. Extracorporeal Hemoperfusion as a Potential Therapeutic Option for Severe COVID-19 patients; a Narrative Review. Arch. Acad. Emerg. Med. 2020, 8, e67.

83. Zhang, C.; Wu, Z.; Li, J.W.; Zhao, H.; Wang, G.Q. Cytokine release syndrome in severe COVID-19: Interleukin-6 receptor antagonist tocilizumab may be the key to reduce mortality. Int. J. Antimicrob. Agents 2020, 55, 105954. [CrossRef]

84. Guo, W.; Ming, F.; Dong, Y.; Zhang, Q.; Zhang, X.; Mo, P.; Feng, Y.; Liang, K. A Survey for COVID-19 Among HIV/AIDS Patients in Two Districts of Wuhan, China (3/4/2020). Available online: https://ssrn.com/abstract=3550029 (accessed on 3 March 2021). [CrossRef]

85. Minotti, C.; Tirelli, F.; Barbieri, E.; Giaquinto, C.; Donà, D. How is immunosuppressive status affecting children and adults in SARS-CoV-2 infection? A systematic review. J. Infect. 2020, 81, e61-e66. [CrossRef] [PubMed]

86. Härter, G.; Spinner, C.D.; Roider, J.; Bickel, M.; Krznaric, I.; Grunwald, S.; Schabaz, F.; Gillor, D.; Postel, N.; Mueller, M.C.; et al. COVID-19 in people living with human immunodeficiency virus: A case series of 33 patients. Infection 2020, 48, 681-686. [CrossRef] [PubMed]

87. Childs, K.; Post, F.A.; Norcross, C.; Ottaway, Z.; Hamlyn, E.; Quinn, K.; Juniper, T.; Taylor, C. Hospitalized Patients with COVID-19 and Human Immunodeficiency Virus: A Case Series. Clin. Infect. Dis. 2020, 71, 2021-2022. [CrossRef]

88. Etienne, N.; Karmochkine, M.; Slama, L.; Pavie, J.; Batisse, D.; Usubillaga, R.; Letembet, V.A.; Brazille, P.; Canouï, E.; Slama, D.; et al. HIV infection and COVID-19: Risk factors for severe disease. AIDS 2020, 34, 1771-1774. [CrossRef]

89. Tesoriero, J.M.; Swain, C.E.; Pierce, J.L.; Zamboni, L.; Wu, M.; Holtgrave, D.R.; Gonzalez, C.J.; Udo, T.; Morne, J.E.; Hart-Malloy, R.; et al. COVID-19 Outcomes Among Persons Living with or Without Diagnosed HIV Infection in New York State. JAMA Netw. Open 2021, 4, e2037069. [CrossRef]

90. BHIVA; DAIG; EACS; GESIDA; Polish Scientific AIDS Society and Portuguese Association for the Clinical Study of AIDS (APECS). Statement on Risk of COVID-19 for People Living with HIV (PLWH) and SARS-CoV-2 Vaccine Advice for Adults Living with HIV. 15 January 2021. Available online: https:/ / www.eacsociety.org/home/bhiva-daig-eacs-gesida-polish-scientific-aidssociety-and-portuguese-association-for-the-clinical-study-of-aids-apecs-statement-on-risk-of-covid-19-for-people-livingwith-hiv-plwh-and-sars-cov-2-vaccine-advice-for-adults-living-with-hiv.html (accessed on 16 January 2021).

91. Pillay-van Wyk, V.; Bradshaw, D.; Groenewald, P.; Seocharan, I.; Manda, S.; Roomaney, R.A.; Awotiwon, O.; Nkwenika, T.; Gray, G.; Buthelezi, S.S.; et al. COVID deaths in South Africa: 99 days since South Africa's first death. S. Afr. Med. J. 2020, 110, 1093-1099. [CrossRef] [PubMed]

92. Lakner, C.; Yonzan, N.N.; Gerszon Mahler, D.; Castaneda Aguilar, R.A.; Wu, H.; Fleury, M. Updated Estimates of the Impact of COVID-19 on Global Poverty: The Effect of New Data; World Bank: Washington, DC, USA, 2020. Available online: https://blogs. worldbank.org/opendata/updated-estimates-impact-covid-19-global-poverty-effect-new-data (accessed on 24 February 2021).

93. Tamuzi, J.L.; Ayele, B.T.; Shumba, C.S.; Adetokunboh, O.O.; Uwimana-Nicol, J.; Haile, Z.T.; Inugu, J.; Nyasulu, P.S. Implications of COVID-19 in high burden countries for HIV/TB: A systematic review of evidence. BMC Infect. Dis. 2020, 20, 744. [CrossRef] [PubMed]

94. Tadolini, M.; Codecasa, L.R.; García-García, J.M.; Blanc, F.X.; Borisov, S.; Alffenaar, J.W.; Andréjak, C.; Bachez, P.; Bart, P.A.; Belilovski, E.; et al. Active tuberculosis, sequelae and COVID-19 co-infection: First cohort of 49 cases. Eur. Respir. J. 2020, 56, 2001398. [CrossRef] [PubMed]

95. Tadolini, M.; García-García, J.M.; Blanc, F.X.; Borisov, S.; Goletti, D.; Motta, I.; Codecasa, L.R.; Tiberi, S.; Sotgiu, G.; Migliori, G.B.; et al. On tuberculosis and COVID-19 co-infection. Eur. Respir. J. 2020, 56, 2002328. [CrossRef]

96. Hsu, D.; Irfan, M.; Jabeen, K.; Iqbal, N.; Hasan, R.; Migliori, G.B.; Zumla, A.; Visca, D.; Centis, R.; Tiberi, S. Post tuberculosis treatment infectious complications. Int. J. Infect. Dis. 2020, 92S, S41-S45. [CrossRef]

97. Sarkar, S.; Khanna, P.; Singh, A.K. Impact of COVID-19 in patients with concurrent co-infections: A systematic review and meta-analyses. J. Med. Virol. 2021, 93, 2385-2395. [CrossRef] [PubMed]

98. Hassan, Z.; Hashim, M.J.; Khan, G. Population risk factors for COVID-19 deaths in Nigeria at sub-national level. Pan. Afr. Med. J. 2020, 35 (Suppl. S2), 131. 
99. Gray, D.M.; Davies, M.A.; Githinji, L.; Levin, M.; Mapani, M.; Nowalaza, Z.; Washaya, N.; Yassin, A.; Zampoli, M.; Zar, H.J. COVID-19 and Pediatric Lung Disease: A South African Tertiary Center Experience. Front. Pediatr. 2021, 8, 614076. [CrossRef] [PubMed]

100. Allwood, B.W.; Koegelenberg, C.F.; Irusen, E.; Lalla, U.; Davids, R.; Chothia, Y.; Davids, R.; Prozesky, H.; Taljaard, J.; Parker, A.; et al. Clinical evolution, management and outcomes of patients with COVID-19 admitted at Tygerberg Hospital, Cape Town, South Africa: A research protocol. BMJ Open 2020, 10, e039455. [CrossRef]

101. Nachega, J.B.; Sam-Agudu, N.A.; Budhram, S.; Taha, T.E.; Vannevel, V.; Somapillay, P.; Ishoso, D.K.; Tshiasuma Pipo, M.; Bongo-Pasi Nswe, C.; Ditekemena, J.; et al. Effect of SARS-CoV-2 Infection in Pregnancy on Maternal and Neonatal Outcomes in Africa: An AFREhealth Call for Evidence through Multicountry Research Collaboration. Am. J. Trop. Med. Hyg. 2020, 104, 461-465.

102. Pai, M. Covidization of research: What are the risks? Nat. Med. 2020, 26, 1159. [CrossRef]

103. Baral, S.; Rao, A.; Rwema, J.O.T.; Lyons, C.; Cevik, M.; Kågesten, A.E.; Diouf, D.; Sohn, A.H.; Phaswana-Mafuya, R.; Kamarulzaman, A.; et al. Competing Health Risks Associated with the COVID-19 Pandemic and Response: A Scoping Review. medRxiv 2021. [CrossRef]

104. Coker, M.; Folayan, M.O.; Michelow, I.C.; Oladokun, R.E.; Torbunde, N.; Sam-Agudu, N.A. Things must not fall apart: The ripple effects of the COVID-19 pandemic on children in sub-Saharan Africa. Pediatr. Res. 2020, 1-10. [CrossRef]

105. Lebina, L.; Dube, M.; Hlongwane, K.; Brahmbatt, H.; Lala, S.G.; Reubenson, G.; Martinson, N. Trends in paediatric tuberculosis diagnoses in two South African hospitals early in the COVID-19 pandemic. S. Afr. Med. J. 2020, 110, 1149-1150. [CrossRef]

106. Schultz, J.; Hyson, P.; Chastain, D.B.; Gharamti, A.A.; Franco-Paredes, C.; Henao-Martínez, A.F. COVID-19 epidemic in the US-A gateway to screen for tuberculosis, HIV, viral hepatitides, Chagas disease, and other neglected tropical diseases among Hispanics. PLoS Negl. Trop. Dis. 2020, 14, e0008953. [CrossRef]

107. Johnson, S.B. Advancing Global Health Equity in the COVID-19 Response: Beyond Solidarity. J. Bioeth. Inq. 2020, 17, 703-707. [CrossRef] [PubMed]

108. Margolin, E.; Burgers, W.A.; Sturrock, E.D.; Mendelson, M.; Chapman, R.; Douglass, N.; Williamson, A.L.; Rybicki, E.P. Prospects for SARS-CoV-2 diagnostics, therapeutics and vaccines in Africa. Nat. Rev. Microbiol. 2020, 1-15. [CrossRef]

109. Gupta, N.; Bhatnagar, T.; Rade, K.; Murhekar, M.; Gangakhedkar, R.R.; Nagar, A.; ICMR COVID Team. Strategic planning to augment the testing capacity for COVID-19 in India. Indian J. Med. Res. 2020, 151, 210-215.

110. Nachega, J.B.; Grimwood, A.; Mahomed, H.; Fatti, G.; Preiser, W.; Kallay, O.; Mbala, P.K.; Muyembe, J.T.; Rwagasore, E.; Nsanzimana, S.; et al. From Easing Lockdowns to Scaling Up Community-based Coronavirus Disease 2019 Screening, Testing, and Contact Tracing in Africa-Shared Approaches, Innovations, and Challenges to Minimize Morbidity and Mortality. Clin. Infect. Dis. 2021, 72, 327-331. [CrossRef] [PubMed]

111. Bulled, N.; Singer, M. In the shadow of HIV \& TB: A commentary on the COVID epidemic in South Africa. Glob. Public Health 2020, 15, 1231-1243. [PubMed]

112. World Health Organization (WHO). The Cost of Inaction: COVID-19-Related Service Disruptions Could Cause Hundreds of Thousands of Extra Deaths from HIV (2020), 11 May 2020. World Health Organization. 2020. Available online: https:/ / www. unaids.org/en/resources/presscentre/pressreleaseandstatementarchive/2020/may/20200511_PR_HIV_modelling (accessed on 9 March 2021).

113. Rademeyer, A. The Ask Afrika COVID-19 Tracker: Unpacking the Significant Social Change Brought on by the COVID-19 Pandemic; Ask Africa: Pretoria, South Africa, 2020.

114. Cox, V.; Wilkinson, L.; Grimsrud, A.; Hughes, J.; Reuter, A.; Conradie, F.; Nel, J.; Boyles, T. Critical changes to services for TB patients during the COVID-19 pandemic. Int. J. Tuberc. Lung Dis. 2020, 24, 542-544. [CrossRef]

115. Enane, L.A.; Christenson, J.C. Global emerging resistance in pediatric infections with TB, HIV, and gram-negative pathogens. Paediatr. Int. Child. Health 2021, 41, 65-75. [CrossRef] [PubMed]

116. Dharmadhikari, A.S.; Mphahlele, M.; Stoltz, A.; Venter, K.; Mathebula, R.; Masotla, T.; Lubbe, W.; Pagano, M.; First, M.; Jensen, P.A.; et al. Surgical face masks worn by patients with multidrug-resistant tuberculosis: Impact on infectivity of air on a hospital ward. Am. J. Respir. Crit. Care Med. 2012, 185, 1104-1109. [CrossRef]

117. Mejia, R.; Hotez, P.; Bottazzi, M.E. Global COVID-19 Efforts as the Platform to Achieving the Sustainable Development Goals. Curr. Trop. Med. Rep. 2020, 1-5. [CrossRef]

118. Mitsuya, H. Fight against COVID-19 but avoid disruption of services for other communicable diseases (CDs) and noncommunicable diseases (NCDs). Glob. Health Med. 2020, 2, 343-345. [CrossRef] 